\title{
The Analysis of Elsa's Growth from the Perspective of Ecofeminism
}

\author{
Yan Wu \\ College of Humanities and Social Sciences, Heilongjiang Bayi Agricultural University, Daqing, China \\ Email: wuyan8011@163.com
}

How to cite this paper: $\mathrm{Wu}, \mathrm{Y}$. (2020). The Analysis of Elsa's Growth from the Perspective of Ecofeminism. Open Journal of Social Sciences, 8, 30-36. https://doi.org/10.4236/jss.2020.86003

Received: May 6, 2020

Accepted: May 30, 2020

Published: June 2, 2020

Copyright $\odot 2020$ by author(s) and Scientific Research Publishing Inc. This work is licensed under the Creative Commons Attribution International License (CC BY 4.0).

http://creativecommons.org/licenses/by/4.0/

\begin{abstract}
The animation movies, Frozen and Frozen II broke the traditional image of the Disney Princesses which needed to "be saved". These two animation movies told the story of Elsa and Anna who experienced the hardships and then to be more mature which reflected the resistant spirit and the feminist spirit. This paper discusses Elsa's growth from a teenage to an adult in these two animations, from which reflected the implied ecofeminist thought of ending the binary opposition between men and women and keeping harmonious coexistence between human beings and nature.
\end{abstract}

\section{Keywords}

Frozen, Frozen II, Female Growth, Elsa, Ecofeminism

\section{Introduction}

Frozen is an American 3D animation movie produced by Disney and directed by Chris Buck and Jennifer Lee in 2013. This animation movie adapted from Hans Christian Andersen's fairy tale "Snow Queen". It was the story of a small country Arendelle covered by ice and snow forever because of Princess Elsa's magic spell. In order to find the summer, Princess Anna teamed up with Kristoff and his reindeer to set out to save the kingdom. The movie won two awards at the 86th Academy Awards. They are "Best Animated Feature" and "Best Original Song" ("Let It Go"). It became the best-selling movie of the year in America.

Six years later, in 2019, Frozen II has been released-the coming-of-age story of Elsa and Anna. Elsa heard the call of a mysterious voice-a voice that promised to reveal the truth of why she had the magic of ice and snow, and the mysterious truth that also threatened her kingdom. Elsa and Anna embarked on an extraordinary adventure once again to the unknown Enchanted Forest and the Dark Sea. In the arduous journey, the affectionateness between Elsa and Anna 
was more shining and moving.

These two animation movies still followed the pattern of "fairy tales of Disney-style", such as princesses and ball gowns, a handsome prince. But some elements of "anti-authority" and "anti-fairy tales" were added, "those elements had been disturbed, just enough, to let something new and different emerge. Prince Hans wasn't charming-he was the villain. The princesses weren't helpless; instead, they saved each other. True love didn't arrive in a rescue-rather, it came from siblings learning to embrace their own strengths." (Duhigg, 2016) The movies broke the pattern of single actress in Disney's "Princess series" animation movies. The protagonist status of the two Princesses is extremely high, forming an independent dual protagonist system (Fan, 2014). The relationship between women becomes the core and main line of these two movies. The two animation movies created two humanized princesses simultaneously for the first time, and abandoned the tradition of puppetry and beautification in princess roles in the past, ushering the return of humanity (Chi, 2016).

Frozen and Frozen II do not fall into the stereotype of a prince saving a princess with a "true love's kiss" as other Disney movies do, but instead highlight the sisterhood and female self-redemption. In the first movie, Elsa overcame her fear, and Anna came to her senses from her blind love. The two sisters completed their first challenges. In the second movie, they continued their "heroic adventure" to find themselves. In the end, Elsa returned to nature and became the "Queen of Nature", while Anna took over the country and became the "Queen of Arendelle". Each of them found their own position and completed the magnificent transformation from Princess to Queen, which was a revolutionary reversal role in the process of female growth. The patriarchal knowledge is powerless to interpret the movies. Because it is a fantasy world supported by matrilineal civilization, goddess civilization and constructed by the true creativity of women. The movies implied that "lost will return"-the return of the goddess, and the return of women.

\section{Ecofeminism}

The thought of ecofeminism originated in the 1970s. It focuses on the relationship between women and nature as well as the relationship between human beings and nature. The concept of ecofeminism was first proposed by French feminist scholar Francoise d'Faubonne. She believes that women's oppression is directly related to the oppressed nature.

Ecofeminism is the product of the combination of feminism and ecological movement, not only one of the important schools of feminist studies, but that of ecological philosophy. Qingqi Wei mentioned in the Ecofeminism that there is an important link between human's possession of nature and men's use of women, so understanding the former leads to understanding the latter, and vice versa (Wei, 2019). "Juxtaposing the goals of the two movements can suggest new values and social structures, based not on the domination of women and nature 
as resources but on the full expression of both male and female talent and on the maintenance of environmental integrity" (Carolyn, 1990).

Ecofeminism is a multicultural perspective that stresses the interconnection between the domination and exploitation of nature and women, asserting that the root cause of the ecological crisis results from both anthropocentrism and androcentrism. It holds that women, nature and art are identical, and that nature and women are both oppressed and ruled. Ecofeminism redefines the relationship between human beings and nature. Human beings are not outside of the nature, and not on the opposite of nature, but part of nature. It seeks ways to liberate nature and women, eliminates dualism, and build an ecological and sustainable society in which men and women, and all species in the natural world live and exist together peacefully and harmoniously.

The scenes of ice and snow, the Enchanted Forest and the Dark Sea, as well as the reindeer and the four spirits in the movies imply the ideas of ecofeminism, ending the domination of men over women and the destruction of nature by human beings, pursuing the self-salvation of women and living in harmony with nature.

\section{Female Growth-A Beautiful Pain}

The women's liberation movement began in the second half of the 19th century and has gone through three waves. The main tasks of feminist movement are to challenge the existing order, to change people's thinking patterns and inherent prejudice against women formed in the patriarchal ideology, so as to improve women's social status. Simone de Beauvoir says in her The Second Sex, "One is not born a woman, but becomes one." (de Beauvoir, 1949, Constance Borde \& Sheila Malovany-Chevallier trans.) As a secondary sex, women have always been the object of oppression. Beautiful, clever, obedient are their all good characters. In other words, women are not born as "women", but are forced to become "women" by the society they live in. Patriarchal societies limit and define women in many ways, making them as the ideal women who men want them to be. Therefore, women are often labeled as "vulnerable, protected, dependent, clever and at home".

When it comes to female growth, we cannot get rid of the special social classification and discrimination brought to women by the binary opposition between men and women in the patriarchal society. Women's growth is bound to go through the process of breaking through the oppression and bondage formed by the patriarchal social concept, to find their own positions and sense of psychological subjects, and then to acquire their new self-images and independent personalities.

\section{1. "Who Am I?" Self-Awakening under the Patriarchy}

Elsa was born with supernatural magic, which brought her and Anna infinite happiness in their childhood. But her magic grew stronger with age. In an acci- 
dent she hurt her younger sister Anna, that made Elsa began to fear her magic. In the name of love, his father ordered the palace to be closed, the gates to be locked, the men to be cut down, and reduced the communication between Elsa and others. Her power should be curbed and suppressed. Out of remorse, but also to protect her younger sister, Elsa chose to close herself, and gradually was distant with Anna. The reason that Elsa became withdrawn was that her personality had been suppressed for so long. Under the father's suggestion, she learned to hide herself, not to move, and to be a good girl. After the death of her parents, Elsa succeeded her father to the throne. At the coronation, she was in great fear with her magic power and tried to keep the dignity of the queen with great care.

Elsa's magical power was exposed and she ran away to the North Mountain intending to live far from society. However, she inadvertently plunged her kingdom into an endless winter and partially froze Anna's heart. The song "Let It Go" is her inner monologue, which reflects the relief after Elsa broke through the oppression to be herself and got rid of the shackles of her inner world. It is full of joy and freedom. Her escape is both a self-exploration against rejection and a self-construction from resistance, not a passive avoidance due to lack of courage to face reality (Wen, 2014). Elsa learned that she could not be afraid of who she was, she could not run away from her own powers. It tells us that you have to embrace your strengths. When women accept and admit their true identities, they are no longer afraid to release their powers and no longer suppress themselves.

Both nature and women are treated by patriarchal (or male-centered) society. Human's domination of nature is based on a patriarchal worldview which legitimizes the domination of women (Wei, 2019). In the male-centered power system, the male is the subject in the dominant position and in charge of all the power and discourse rights. The female is the object, the objectified object and the mute other. Women cannot show their true humanity and nature under the social consciousness of the patriarchy. They are always in a passive state and are required to learn to hide and control themselves. A part of the women is submissive and no-resistance due to long-term bondage and oppression. However, women are not inherently weak, but are influenced by social ideology and habitually think of themselves as "women", thus positioning themselves as the weak. Elsa throw her crown away as a symbol of saying goodbye to "the past" and becoming the queen of her life. Women could become what they want to be if they have a deep identification with their own gender and regard themselves as persons with independent personality. Seeking firm belief from setbacks and locating self-position in confusion are the necessary factors for women's awakening of consciousness, as well as important signs for women to truly explore their self-values. Women can get rid of the oppression of the patriarchy, can change their own situation and destiny, and can become the subjects of life and the masters of destiny. 


\section{2. "Where Am I from?" the Self-Exploration under the Call of Motherhood}

The innate magic power makes Elsa as a mythical figure with great power and with a slightly foreordination. Elsa returned to the real society in the face of the reality. She was no longer afraid of her magic power. After adjusting to the society, Elsa inherited the throne. She completed the construction of her social identity. But where did her magic power come from? What was the cause of her parents' death? These questions puzzled her for a long time. In Frozen II, a mysterious voice called for Elsa again and again, guiding her back to the Enchanted Forest, to find the answer to the mystery of her life and the source of magic power. Therefore, the sisters set out on an unknown journey to find their own identities. Compared with the Frozen, the place of Elsa and Anna's second adventure has shifted from the palace to the nature, with deeper stories and larger scenes.

The four spirits appeared in the second film "air, fire, water and earth" come from the ancient Greek theory of the world's material composition. They represent the four seasons of spring, summer, autumn and winter respectively, which are also metaphors of nature. From the relationship between Elsa and the spirit of fire, it has been suggested that Elsa (female) is the all-pervade goddess, that is, the symbol of nature itself. The law of women is the law of nature. The process of Elsa conquest the water spirit is a manifestation of the female principle. Water is a female symbol and the root of life. Elsa tamed these four spirits through her magic. And Honeymaren said there was a fifth spirit, a bridge between magic nature and human beings. Elsa is the fifth spirit, the most critical part. Her magic came from nature, that is why Elsa chose to stay in the north at the end of the movie.

This fifth spirit is actually the symbol of women. The four spirits without Elsa had become a strong force against nature, and the society without women would inevitably be out of balance. Men and women have different perspectives in the construction of ecological culture, because of their traditional division of social roles and the differences in production and life experience. The close relationship between ecological environment and women's development enables women to play a more active role in the construction and inheritance of ecological culture. They are not only participants and practitioners, but also important creators and communicators. For women in modern society, they play the roles of daughter, wife and mother in the families, as well as the roles of superiors, subordinates and colleagues in the workplaces. The diversified roles make women constantly change their roles in different scenes. They must coordinate various personnel relations and deal with the relationship between their careers and families. The unique role of women is indispensable in family, work and society. Once women identify with their gender, they will gain the awakening of self-consciousness, break through the traditional cognition of women, then show great inner strength, and fight for their ideals and goals. 


\section{3. "Where Am I going?" Self-Transcendence after Returning to Nature}

In Frozen II, the kingdom of Arendelle was in crisis because of a plot carried out by their grandfather, the old king Runard that left the Enchanted Forest shrouded in fog. It implied the men's destruction of nature. In the face of the serious mistake made by their grandfather, Elsa and Anna did not run from it, but to bravely face the mistake and solve it. This shows their extraordinary courage and perseverance. At the same time, Elsa's power makes her bear the burden to save the world with the power of women. In the end, Elsa solved the problem of the dam. It seemed that the Frozen II was more like a test of nature to human beings. The Enchanted Forest was a symbol of the natural way, as well as a revelation of the feminine law and a reflection on the consequences of violating the feminine law. It is a very important feature that ecofeminism analyzes and explains the relationship between human beings and nature by adhering to the principle of women and opposing patriarchy.

The return of Elsa also symbolizes the return of women's rights and consciousness. In the balance of nature, the four spirits of nature can operate normally and coexist harmoniously. Elsa belongs to nature. Only by returning to nature and exerting her "magic" can she realize her value. The magic changed from "negative" to "positive", and Elsa became the queen with confident. Ecofeminism advocates the combination of the nature and the feminist spirit. Women's reference is nature and life itself, not men, not love. Women are able to live in harmony with nature and have a closer relationship with it. To a certain extent, women's character and the return of women can solve some of the existing social shortcomings. Because women are more humane than men, they pay more attention to the relationship between human beings and nature, and that of human beings and creatures. They advocate love and interdependence instead of confrontation and separation.

Women can be "superwomen" or they can "save" the world with their own power. Modern society has provided a big stage for women. And more and more women are participating in various fields with their powers. Women are no longer to be limited in the family and the kitchen, they can go out of the family, participate many activities in society.

\section{Conclusion}

In the two movies, Elsa is a shining star, the representative of independent women in the new era. Her experiences reflected the growing process of the female inner spirits. Elsa's self-questioning and self-exploration are the main lines of both movies. Both movies focus on the women's league and the roots of female power. The two sisters traced their mother's love and songs to seek the truth of their own lives and to the truth of the world (the law of women). From Arendelle to the Enchanted Forest in the north, from the pursuit of individual liberation to bear the mission and then return to nature, Elsa' growth reflects the 
return of human nature and the return of women. She is able to fight for what she wants with her own strength. Elsa shows the awakening of female self-awareness in twenty-first century, independent in personality and spirit. Women with a clear goal gradually become the subject of life. They are no longer weak, but have strong and infinite strengths. Women's awakening is not only related to their own growth, but also closely related to the development of society. It is the inevitable trend of ecological balance in the aspect of gender. Only when women learn to grow by themselves and improve their inner strength, can women become more powerful.

\section{Acknowledgements}

This paper was supported by the foreign language research project of Heilongjiang Province Social Science in 2018, project No.WY2018089-C.

\section{Conflicts of Interest}

The author declares no conflicts of interest regarding the publication of this paper.

\section{References}

Carolyn, M. (1990). The Death of Nature: Women, Ecology, and the Scientific Revolution. San Francisco: Harper One Publication.

Chi, Y. L. (2016). The Analysis of the Evolution of Disney Princesses. Frozen, Movie Literature, 23, 117-119.

de Beauvoir, S. (1949). The Second Sex (Translated by Constance Borde \& Sheila Malovany-Chevallier). New York: Random House.

Duhigg, C. (2016). Smarter Faster Better: The Secrets of Productivity in Life and Business. New York: Random House.

Fan, Zh. (2014). Frozen: The Twins of Ice and Fire. Forum of Arts, 8, 45-47.

Wei, Q. Q., \& Li, J. L. (2019). Ecofeminism. Beijing: Foreign Language Teaching and Research Press.

Wen, L. (2014). The Analysis of the Women's Growth. Frozen, Sichuan Drama, 12, 99-101. 